\title{
Socio-Demographic Factors Influencing the Extent of Residential Green Spaces in Galle City, Sri Lanka
}

Buddhini Chathurika Jayasinghe, University of Ruhuna, Sri Lanka

G. P. T. S. Hemakumara, Department of Geography, University of Ruhuna, Sri Lanka

Piyadasa Hewage, University of Ruhuna, Sri Lanka

\begin{abstract}
Due to increasing urbanization, the distribution of human settlements is changing and this has led to the rapid decline of vegetation cover in cities and townships. Urbanization tends to decrease the proportion of land that is dedicated to public green spaces. Therefore, residential gardens (private gardens) will need to play a major role in contributing to urban green space in future though presently little attention is given to their relative value and importance. Several factors influence the function of residential gardens in an urban area. The main objective of this paper is to evaluate the socio demographic factors that influence the size and presence of residential green spaces in an urban residential zone. As a case study, this research selected a primary residential zone in Galle City, Sri Lanka. Every housing unit $(\mathrm{n}=280)$ in a residential zone was surveyed to collect the data for multiple regression analysis. The analysis showed that factors such as land extent (LE), nature orientation (NO), perceptions about advantages of growing residential greenery (PA), perception about disadvantages resulting from residential garden (PDA), occupational status (husband and wife are not occupied) $\left(D_{1}\right)$, and their educational level (higher than degree) $\left(D_{2}\right)$ significantly affect to the extent of green area maintained by an urban residence. The relationship between extent of residential green space (EGA) and socio demographic factors can be explained by this model: EGA $=0.091+0.003 \mathrm{LE}+$ $0.060 \mathrm{NO}+0.030 \mathrm{PA}-0.040 \mathrm{PDA}+0.198 \mathrm{D}_{1}+0.240 \mathrm{D}_{2}$.
\end{abstract}

\section{KEYWORDS}

Functions of Residential Garden, Green Space, Private Garden, Residential Greenery, Urbanization

\section{INTRODUCTION}

In the year 1990, less than $40 \%$ of the global population lived in cities, but as of 2010 , more than onehalf of all people were living in an urban area. By the year 2030, 6 out of every 10 people will live in a city, and by 2050 this proportion will increase to 7 out of 10 people (UN HABITAT, 2014). As a result of urbanization and densification, the consumption of land by new residential developments can lead to a loss of green spaces (Kabisch et al., 2015).

\section{DOI: 10.4018/IJEPR.2021010104}

This article, published as an Open Access article on November 27, 2020 in the gold Open Access journal, International Journal of EPlanning Research (converted to gold Open Access January 1, 2021), is distributed under the terms of the Creative Commons Attribution License (http://creativecommons.org/licenses/by/4.0/) which permits unrestricted use, distribution, and production in any medium, provided the author of the original work and original publication source are properly credited. 
Urbanization has brought the convenience of city life to many people but has also subjected them to a harsher environment. Urban environmental problems such as air pollution, noise, and urban 'heat island' effect pose serious risks to the health of urban residents (Douglas, 2012). With the increased concern on climate changes, urban greening has gained new importance by serving as a low-cost approach for cities to mitigate and adapt to these changes (Gill, S. E., et al., 2007).

There has been growing interest in urban green space research due to evidence that nature positively impacts human wellbeing (Frumkin, 2013, Taylor \& Hochuli, 2015). Extensive studies have shown that urban green spaces can generate multiple environmental benefits, including cleaning the air, lowering noise levels, reducing urban heat island intensity, and improving storm water runoff quality (McPherson and Simpson, 2002). Urban green spaces can also provide significant psychological and socio-economic benefits to their residents such as relieving stress and increasing property value (Fuller et al., 2007).

Urban green spaces are vegetated public and residential (private) spaces in cities that are typically categorized by land use and land cover (Kendal et al., 2016). Most research attention has been paid to sizable urban green spaces such as urban parks and urban forests (Jauregui, 1990/1991; Chang et al., 2007; Chen and Wong, 2006), not much work focuses on the micro-scale greening and residential gardens.

Residential gardens are recognized as an important component of urban green space (Loram et al., 2007), but their specific contribution has rarely been assessed. Urbanization naturally tends to decrease the extent of land that is dedicated to gardens (Mathieu, R., Freeman, C., Aryal, J., 2007 \& Smith, C., 2010). Within this context, residential gardens play a major role in green infrastructure (Loram, A., Tratalos, J., Warren, P.H., \& Gaston, K.J., 2007) though little attention is given to their value and importance.

In low-density cities with extensive suburban areas, private gardens represent a large proportion of the overall urban green infrastructure network (Cameron et al., 2012; Ghosh \& Head, 2008; Loram et al., 2007). Private residential land in Sydney provides $43 \%$ of foliage cover and $77 \%$ of Australian capital city residences have one or more trees in their private gardens (Kirkpatrick et al., 2011; Lin et al., 2015). More than 50\% of total greenspace in Dunedin, New Zealand comes from private gardens (Mathieu, Freeman, \& Aryal, 2007). Lin et al. (2015) suggest that residential areas present the largest opportunity for increasing tree cover in cities.

A large number of studies, especially in Western countries, have looked at how residential green spaces are used and function. However, scientific evidence for residential garden in Sri Lanka is hard to find there are no any studies carried out to understand the residential garden practices in urban cities in Sri Lanka. However residential garden in the highly populated Wet zone have suffered a considerable degradation in the past two decades due to fragmentation and urbanization in Sri Lanka (Pushpakumara, et al, 2010).

Socioeconomic variables (e.g. population, housing density, education, and home ownership) were apparently better predictors of the extent and type of vegetation cover in private garden than biophysical variables (e.g. rainfall, soil fertility, and solar radiation, etc.) (Luck et al., 2009). A range of factors influences the presence and size of the residential gardens in an urban area. Therefore, this paper sought to investigate the impact of socio demographic factors to the size of residential green spaces in a highly urbanized city in Sri Lanka.

The research objectives are:

1. Identifying all socio demographic factors that influence the size and presence of a residential green space.

2. Assessing the most significant factors effect on the size and presence of a residential green space.

3. Developing a model to illustrate the relationship between the extent of residential green space and socio demographic factors in an urban settlement. 


\section{LITERATURE REVIEW}

\subsection{Urban Green Space and Residential Greenery}

Though the definition of green space has for long been argued about, a universally accepted definition is still lacking (Byomkesh et al., 2012). The European Commission (2013) defined green space as a strategically planned network of high quality natural and partly built-up areas replete with many environmental features, which is designed and managed to deliver a wide range of ecosystem services and protect biodiversity in both rural and urban settings. In other words, urban green space is land situated in urban areas with natural surfaces of bare soil or soil covered with vegetation (Swanwick et al., 2003, p97).

Jim and Chen (2003) defined urban green spaces as vegetated areas found in urban environments that could be described as semi-natural areas such as parks, forest patches, open spaces, residential gardens and long row of trees lining one or both sides of a roadway.

Urban green spaces includes a range of landscape types of varying complexity and morphology including parks, public green spaces, allotments, green corridors, street trees, urban forests, roof gardens, vertical greenery on walls and private(Residential) gardens (Cameron et al., 2012).

Cameron et al.'s (2012, p.129) definition of Residential garden as "the area adjoining a private dwelling, whether it is owned or rented" means that it is not accessible to the general public. Residents' autonomy over the garden is a key feature of residential gardens, although householders may give the design and maintenance responsibilities to other parties such as landscape architects, professional gardeners or caretakers. Residential gardens vary in form, function and size (Cameron et al., 2012). Garden size is closely associated with housing type and density (Whitford et al., 2001). In a study of five English cities, Loram et al. (2007) found that while terraced houses were the most numerous of three housing types in each of these cities, semi-detached and detached houses had the highest cumulative area of gardens.

\subsection{Importance of Residential Gardens}

With the world's urban population continuing to grow rapidly, many cities are transitioning to higher density, compact housing (Loibl \& Toetzer, 2003; Radeloff, Hammer, \& Stewart, 2005). Urban growth will inevitably lead to changes in urban vegetation cover and access to private green space - that is, people's private (domestic) gardens, back yards, and front yards. In areas of high residential density, each householder's green coverage is likely to either disappear or decline in size, while people living in the sprawling outskirts of cities may still have the opportunity to choose both the size and natural content of these spaces (Conway \& Hackworth, 2007; Lowry, Baker, \& Ramsey, 2012).

Residential gardens are important because they provide city residents with immediate access to urban green space (Gaston, Warren, Thompson, \& Smith, 2005; Shanahan, Lin, Gaston, Bush, \& Fuller, 2014). However, they also play a significant role in contributing to overall vegetation cover in cities, as residential areas contribute to more than $50 \%$ of all available green space in many cities (Gaston et al., 2005; Lin, Meyers, \& Barnett, 2015; Loram, Tratalos, Warren, \& Gaston, 2007; Mathieu, Freeman, \& Aryal, 2007; Shanahan et al., 2014).

According to previous research, both public green spaces and private gardens can provide similar benefits. These include opportunities for social interaction and enhancement of social cohesion (Cheng \& Pegg, 2016; Peters et al., 2010; Shanahan et al., 2015), improving mental health and sense of well-being (Cervinka et al., 2016; Cheng \& Pegg, 2016; Lee \& Maheswaran, 2011; Shanahan et al., 2015), and positively contributing to biodiversity (Cameron et al., 2012; Kong et al., 2010; Vickery, 1995). Private gardens bring socioeconomic benefits to local communities by improving the locality and raising property values (Clayton, 2007; Tyrvainen, 1997).

Vegetation around the home can provide a variety of important ecosystem services that contribute to human and environmental health at local, neighborhood, and regional scales (Bolund \& Hunhammar, 1999). For example, benefits such as climate regulation, shade and shelter can be delivered passively 
even when the human recipient does not actively spend time in the yard (Bowler, Buyung-Ali, Knight, \& Pullin, 2010). These benefits can reduce the energy requirements for air conditioning and lower the peak demand for energy, thereby reducing consumer costs in residential homes (McPherson, 1994). The physical presence of vegetation around the home can also provide benefits of noise reduction by buffering residential areas from urban noise pollution, and enhance privacy by blocking the views from neighboring properties.

\subsection{Factors Influencing the Function of Residential Greenery}

Socioeconomic variables (e.g. population, housing density, education, and home ownership) were apparently better predictors of the extent and type of vegetation cover in private gardens than biophysical variables (e.g. rainfall, soil fertility, and solar radiation, etc.) (Luck et al., 2009). Larger domestic gardens (Smith et al., 2005), those associated with older properties (Hope et al., 2003), or with higher income or tertiary-educated residents tended to have proportionally more vegetation, greater diversity of plants, and more complex garden styles (Daniels \& Kirkpatrick, 2006).

A range of factors influences the amount and type of vegetation in people's yards and Cultural background, demographics, housing type and ownership can all affect the decision to plant and maintain vegetation in private green spaces (Grove et al., 2006; Perkins, Heynen, \& Wilson, 2004; Troy, Grove, O'Neil-Dunne, Pickett, \& Cadenasso, 2007). For instance, people who own their own homes may be more likely to invest in tree cover to save money on heating and cooling or to enhance privacy (Bowler et al., 2010; Summit \& McPherson, 1998). How long the suburb has been in existence also directly influences tree cover because in younger suburbs insufficient time would have elapsed for trees to be planted and become mature (Greene, Millward, \& Ceh, 2011).

There is also a range of other factors that can discourage planting of new vegetation, or even encourage removal of existing vegetation. For example, in some locations the fear of assisting the spread of bushfires in hot and dry conditions can discourage planting around the home (Gilbert \& Brack, 2007). Furthermore, the presence of dense urban vegetation is often associated with increased fear of crime (Gobster \& Westphal, 2004; Nasar \& Jones, 1997). Tree maintenance requires time, effort, and knowledge, as well as space, which is a scarce commodity in densely populated areas (Kirkpatrick et al., 2011; Summit \& McPherson, 1998). Large trees around homes or near roads can cause damage or threaten foundations and other infrastructure due to the spread of heavy roots while large overhanging branches can also create safety issues (Head \& Muir, 2005; Nowak \& Dwyer, 2007). Pondering this range of possibilities and the barriers against planting and maintaining vegetation around the home, a growing body of research shows that socioeconomic and demographic factors are correlated with tree cover and species diversity within yards (Clarke, Jenerette, \& Davila, 2013; Kirkpatrick, Daniels, \& Zagorski, 2007; Shanahan et al., 2014; van Heezik, Freeman, Porter, \& Dickinson, 2013).

Furthermore, considerable evidence now shows that socio-demographic factors (including gender, age, education, income and nature orientation) influence to the maintain a private green spaces (Ho et al., 2005; Lin, Fuller, Bush, Gaston, \& Shanahan, 2014; Zanon, Doucouliagos, Hall, \& Lockstone-Binney, 2013).

Table 1 summarized all the factors influences to the presence and size of residential gardens in an urban area. Table 2 shows the selected socio demographic variables for this research study.

When review the scientific literature on residential green space, most of the research have done in the context of community gardening, urban agriculture and home gardening. These researches gathered evidence of the benefits of gardening and food growing in relation to specific health and wellbeing issue.

They have used various methods to identify factors influencing participation in edible gardening and/or urban agriculture. The method such as descriptive case studies, comparative studies, surveys of participants and typology studies have been used to identify many types of influential factors including economic, institutional, cultural, social, and demographic factors. 
Table 1. Summary of factors influencing the residential gardens

\begin{tabular}{|c|c|c|}
\hline $\begin{array}{l}\text { Factor Associated With } \\
\text { Function of Residential } \\
\text { Garden }\end{array}$ & Determining Factor & Authors \\
\hline Presence and size of yards & History and types of urban development & $\begin{array}{l}\text { Conway \& Hackworth, 2007; Gill, } \\
\text { Handley, Ennos, Pauleit, Theuray, \& } \\
\text { Lindley, 2008; Smith, Gaston, Warren, } \\
\& \text { Thompson, } 2005\end{array}$ \\
\hline $\begin{array}{l}\text { Proportion of green space } \\
\text { available }\end{array}$ & Housing type and density & Whitford et al., 2001 \\
\hline \multirow[t]{2}{*}{$\begin{array}{l}\text { Extent and type of vegetation } \\
\text { cover in private gardens }\end{array}$} & $\begin{array}{l}\text { Socioeconomic variables } \\
\text { e.g. population and housing density, } \\
\text { education, home ownership }\end{array}$ & Luck et al., 2009 \\
\hline & $\begin{array}{l}\text { Biological variables } \\
\text { e.g. rainfall, soil fertility, solar radiation }\end{array}$ & Luck et al., 2009 \\
\hline Abundance of vegetation & Physical characteristics of cities & $\begin{array}{l}\text { Kirkpatrick, Davison, \& Daniels, 2012; } \\
\text { Loram et al., 2007; Shanahan et al., } \\
\text { 2014; Smith } \text { et al., } 2006\end{array}$ \\
\hline $\begin{array}{l}\text { Decision to plant and maintain } \\
\text { vegetation in private green } \\
\text { spaces }\end{array}$ & $\begin{array}{l}\text { Cultural background, demographics, } \\
\text { housing type and ownership }\end{array}$ & $\begin{array}{l}\text { Grove } \text { et al., 2006; Perkins, Heynen, \& } \\
\text { Wilson, 2004; Troy, Grove, O’Neil- } \\
\text { Dunne, Pickett, \& Cadenasso, } 2007\end{array}$ \\
\hline $\begin{array}{l}\text { Invest in tree cover to save } \\
\text { money on heating and cooling } \\
\text { and to enhance privacy }\end{array}$ & Home ownership & $\begin{array}{l}\text { Bowler et al., 2010; McPherson et } \\
\text { al,1998 }\end{array}$ \\
\hline \multirow{4}{*}{$\begin{array}{l}\text { Factors that discourage the } \\
\text { planting and maintenance of } \\
\text { vegetation }\end{array}$} & $\begin{array}{l}\text { Fear of increased potential for bushfires } \\
\text { in hot and dry conditions }\end{array}$ & Gilbert \& Brack, 2007 \\
\hline & $\begin{array}{l}\text { Presence of dense vegetation cover likely } \\
\text { to instill fear of crime }\end{array}$ & $\begin{array}{l}\text { Gobster \& Westphal, 2004; Nasar \& } \\
\text { Jones, } 1997\end{array}$ \\
\hline & $\begin{array}{l}\text { Tree maintenance requires time, effort, } \\
\text { and knowledge, as well as space that is a } \\
\text { scarce commodity in densely populated } \\
\text { areas }\end{array}$ & $\begin{array}{l}\text { Kirkpatrick et al., 2012; Summit \& } \\
\text { McPherson, } 1998\end{array}$ \\
\hline & $\begin{array}{l}\text { Vegetation with heavy roots around } \\
\text { homes or near roads can cause damage or } \\
\text { threaten infrastructure; large overhanging } \\
\text { branches can create safety issues }\end{array}$ & $\begin{array}{l}\text { Head \& Muir, 2005; Nowak \& Dwyer, } \\
2007\end{array}$ \\
\hline $\begin{array}{l}\text { Tree cover and species diversity } \\
\text { within yards }\end{array}$ & Socioeconomic and demographic factors & $\begin{array}{l}\text { Clarke, Jenerette, \& Davila, 2013; } \\
\text { Kirkpatrick, Daniels, \& Zagorski, } \\
\text { 2007; Shanahan et al., 2014; van } \\
\text { Heezik, Freeman, Porter, \& Dickinson, } \\
2013\end{array}$ \\
\hline $\begin{array}{l}\text { Amount of time that people } \\
\text { spend in green spaces }\end{array}$ & Nature orientation & Lin et al., 2014 \\
\hline $\begin{array}{l}\text { What induces people to spend } \\
\text { more time in their private yards }\end{array}$ & $\begin{array}{l}\text { The vegetation content of private yards } \\
\text { and socio-demographic factors }\end{array}$ & $\begin{array}{l}\text { Arnold \& Lang, 2007; Graesch, } \\
\text { Broege, Arnold, Owens, \& Schneider, } \\
2006\end{array}$ \\
\hline
\end{tabular}

Source: Developed by Author,2019

Some researchers have conducted case studies in which they created a profile of edible gardeners in an area. For example, Miura et al. (2003) profiled 152 urban edible gardeners in Davao City, in the Philippines, noting their age, education, family size, family income, household food consumption 
Table 2. Selected variables for the study

\begin{tabular}{|c|c|c|c|}
\hline No. & Variable & Description & Unit of Measurement \\
\hline 1 & Land extent & Total lot size & Perch \\
\hline 2 & $\begin{array}{l}\text { Vegetation cover of } \\
\text { yard }\end{array}$ & $\begin{array}{l}\text { Percentage of area used as } \\
\text { residential garden out of the total } \\
\text { land space available for gardening }\end{array}$ & $\%$ \\
\hline 3 & $\begin{array}{l}\text { Year in which the home } \\
\text { was built }\end{array}$ & House build year & Year \\
\hline 4 & Housing type & Type of house & $\begin{array}{l}\text { Single house - single story } \\
\text { Single house - two story } \\
\text { Single story - out of multi-story Attached } \\
\text { house/ annex } \\
\text { Raw house/ line house } \\
\text { Hut/ shanty }\end{array}$ \\
\hline 5 & Ownership of home & Land Tenure & Owned/ Rented/ Leased/ Encroached \\
\hline 6 & Household size & $\begin{array}{l}\text { Total number of people living in the } \\
\text { home }\end{array}$ & Number \\
\hline 7 & Children in the home & $\begin{array}{l}\text { Number of children living in the } \\
\text { home }\end{array}$ & Number \\
\hline 8 & Occupation & $\begin{array}{l}\text { Employment details of the person } \\
\text { who maintains the home garden }\end{array}$ & $\begin{array}{l}\text { Dual career/ only husband works/ only } \\
\text { wife works/ both are non-occupied }\end{array}$ \\
\hline 9 & Householder's income & Householder's average income & Rs. \\
\hline 10 & $\begin{array}{l}\text { Educational } \\
\text { background }\end{array}$ & $\begin{array}{l}\text { Highest formal educational } \\
\text { qualification }\end{array}$ & $\begin{array}{l}\text { Lower than } \mathrm{O} / \mathrm{L}, \mathrm{O} / \mathrm{L} \text { pass, } \mathrm{A} / \mathrm{L} \text { pass/ } \\
\text { degree/ higher than degree }\end{array}$ \\
\hline 11 & Cultural background & Cultural background & Buddhism/ Hinduism/ Islam/ Christianity \\
\hline 12 & Nature orientation & $\begin{array}{l}\text { The affective, cognitive, and } \\
\text { experiential relationship individuals } \\
\text { have with the natural world }\end{array}$ & $\begin{array}{l}\text { Asked participants to respond to } \\
\text { statements concerning their nature } \\
\text { orientation. Items can then be averaged } \\
\text { to produce a nature relatedness score. }\end{array}$ \\
\hline 13 & Time spent in the home & $\begin{array}{l}\text { The total time spent in the home per } \\
\text { day for maintaining the home garden }\end{array}$ & hours \\
\hline 14 & $\begin{array}{l}\text { Perception about } \\
\text { advantages of } \\
\text { residential gardening }\end{array}$ & $\begin{array}{l}\text { Consider the benefits that residents } \\
\text { can gain from residential gardening }\end{array}$ & $\begin{array}{l}\text { Asked participants to respond to } \\
\text { statements concerning the benefits of } \\
\text { residential greenery. The items can then } \\
\text { be averaged to find their perceptions } \\
\text { regarding advantages received from } \\
\text { residential garden. }\end{array}$ \\
\hline 15 & $\begin{array}{l}\text { Perception about } \\
\text { disadvantages of } \\
\text { residential gardening }\end{array}$ & $\begin{array}{l}\text { Consider the factors that can } \\
\text { discourage residents from planting } \\
\text { new vegetation, or even encourage } \\
\text { them to remove old vegetation. }\end{array}$ & $\begin{array}{l}\text { Asked participants to respond to } \\
\text { statements concerning the factors } \\
\text { that can discourage residents from } \\
\text { planting new vegetation. Items can } \\
\text { then be averaged to produce Index of } \\
\text { Socioeconomic Disadvantage. }\end{array}$ \\
\hline
\end{tabular}

costs, yard size, number of varieties of fruits and vegetables planted, and body mass index. This research approach cannot determine the relative influence of different factors on gardening behavior.

A few studies (Maxwell, 1995; Mazereeuw, 2005; Mwangi, 1995) have compared the demographic characteristics of gardeners with non-gardeners in urban settings. For example, a telephone survey of urban residents of the Waterloo region in Canada found that the proportion of residents who grew food on their private, residential properties was found to be the same across gender, age and income 
groups (Mazereeuw, 2005). However, residents who had lived in Canada for more than 10 years were more likely to grow their own food than those who had lived in Canada for less than 10 years. Mwangi (1995) and Maxwell (1995) also found that length of stay affected the probability of participation in urban agriculture in Nairobi (Kenya) and Kampala (Uganda), respectively. Additionally, Maxwell found that larger households were more likely to grow food.

Another strategy for explaining the factors that influence urban agriculture is to create typologies. Typologies are used as a means to explain clusters of factors influencing an activity or behaviour. Moustier and Moustier, P., \& Danso (2006) created four types: home subsistence farmers, familytype commercial farmers, entrepreneurial farmers and multicropping peri urban farmers. Whereas, Kortright (2007) observed Toronto residents with edible backyards who did not fit into any of Moustier and Danso's four types and created another five types: cook gardeners, teaching gardeners, environmental gardeners, hobby gardeners, and aesthetic gardeners. Neither of these studies used empirical methods to create the typologies.

Although numerous studies have identified possible factors influencing gardening behaviors, none have measured the relative influence of socio demographic variables on the extent of size and presence of residential garden. To determine the relative influence of variables on participation in edible gardening, one would need to test a predictive model. For example, Blaylock and Gallo (1993) used a predictive model to determine the factors influencing the decision to produce vegetables at home in the USA. However, they restricted their model to external factors. To date, no studies have sought to determine the relative influence of socio demographic determinants on the size and presence of residential gardening.

In order to fill this gap in the literature, this research will determine which socio-demographic factors have the greatest influence on size and presence of residential gardening. Filling this research gap will contribute to a greater understanding of function of residential green spaces which can then be used to promote it. Understanding and promoting residential gardening in is important because gardening has numerous benefits.

By go through with the literature, we identified 14 socio demographic variables (Table 2)which are influencing to the size and presence of residential green space and then use multiple regression analysis to study the relationship between independent and dependent variable. Regression analysis can provide insights that few other techniques can. The key benefits of using regression analysis are that it can: Indicate if independent variables have a significant relationship with a dependent variable, indicate the relative strength of different independent variables' effects on a dependent variable and Make predictions (Eric Mool, 2014).

\section{MATERIALS AND METHOD}

\subsection{Study Area}

The City of Galle is located at Latitude $6.01^{\circ} \mathrm{N}$ and Longitude $80.13 \mathrm{E}$ in the Wet Zone, which is the most urbanized region in Sri Lanka. It is the largest town in the Southern Province and functions as the District and Provincial capital of the Southern Region. This town is located in the wet zone receives rain from South-West Monsoon with an annual rainfall of $2377.9 \mathrm{~mm}$. Annual average temperature is $26.70 \mathrm{C}$ and the humidity ranges from $80-88 \%$. The Galle Municipal Council area covers an extent of 1742.4 hectares, and consists of 15 wards (Figure 1).

This urban area was first established as a municipality on 01.01 .1867 according to the gazette notification no. 3571 issued by the Governor on 24.11.1866 under the Urban Council Ordinance of 1865. More recently, it had been recognized that there was a necessity to have planned development due to the population growth and other urban issues. Therefore, this town had been declared as an urban development area under Section 3 of the UDA Act No 41 of 1978 by Gazette Extraordinary notification No. 38/16 of 01.06.1979 for the purpose of formalizing the urban diversity arising with the population growth in the town. 


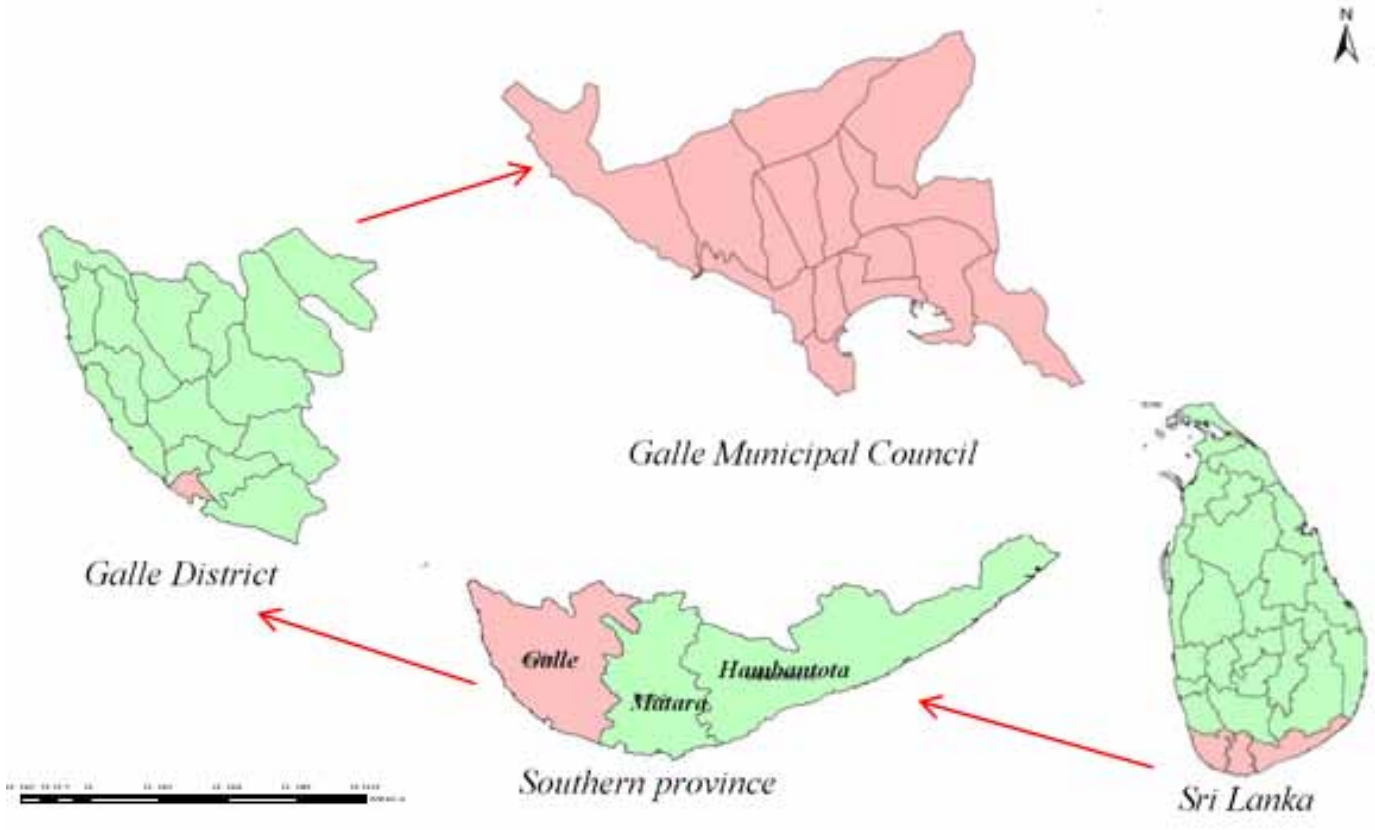

Proposed Zoning Plan was prepared based on the development requirements of the town up to the planned period of 2025. Accordingly, the town was divided into 11 zones (Figure 2).

According to the proposed zoning plan (2008-2025) of the Urban Development Authority, eight primary residential zones have been demarcated within the Galle MC (Figure 3). According to the analysis done by C. Jayasinghe et all,2018 by measuring the suitability levels using GIS based weighted overlay analysis based on four key criteria such as level of infrastructure, land value, road accessibility, and proximity to town center the "Primary residential zone 6" is the best residential zone in Galle MC region(Figure 4). Therefore this zone is selected as the case study for this research; there are 280 housing units and represent $4 \%$ housing units from all residential zone (Table 3 ).

There are 280 housing units in the selected sample and 14322 population. There are 112 house owners are Buddhists, 162 are Islamic and 6 are Christians. When concern about the detail of housing, 189 houses are single story, 63 are two story, 14 are more than 2 storied houses. There are 2 annex type houses and 6 shanties. 264 houses are owned by themselves and 16 houses are rented houses.

76 households have less than 6 perch land lot, 83 have 6-10 perch land, 68 have $10-15$ perch land, 27 have 15-20 land extent and 26 householders have more than 20 perch land extent.

\subsection{Data Collection}

Survey was conducted on 280 housing units using the questionnaire survey method as the data collection technique and Participants were the owners of the housing units. There were 16 questions (Appendix A) covering three sub-topics: a) basic information regarding the residents, condition of house and land, b) green coverage, and c) peoples' attitudes towards green coverage. 5-point Likert scale-style questions used to get the details on nature orientation and participant's perception about advantages and disadvantages resulting from gardening. The data analysis of this study was performed using a multiple regression model. In this study 14 variables were used (Figures 5). 


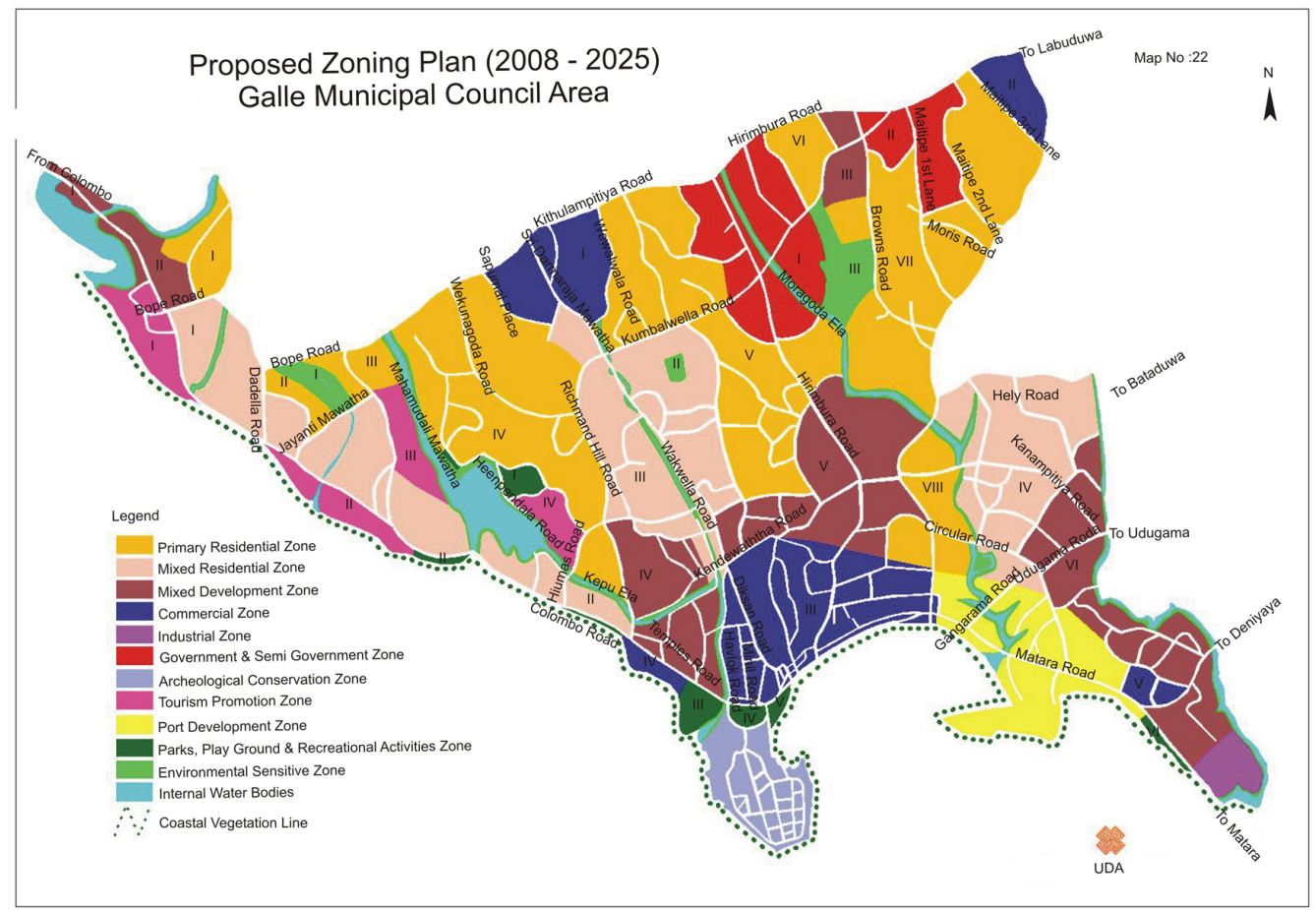

Figure 3. Primary residential zones of Galle MC

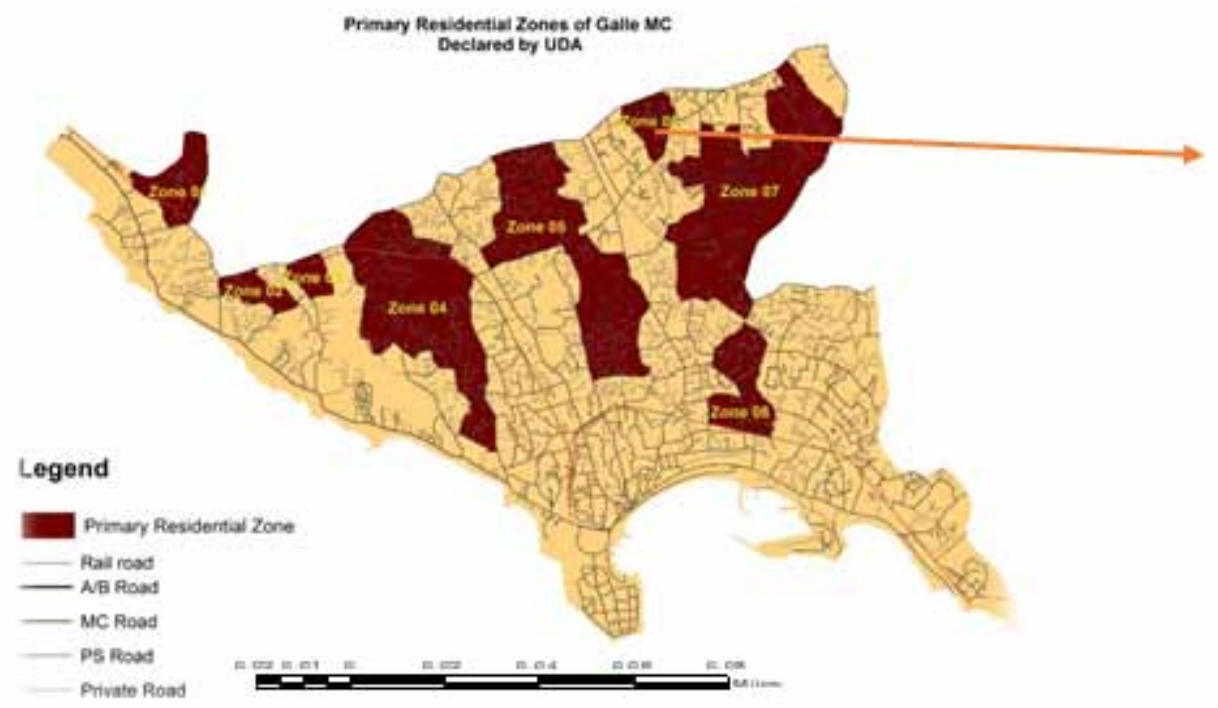


Figure 4. Primary residential zone 06

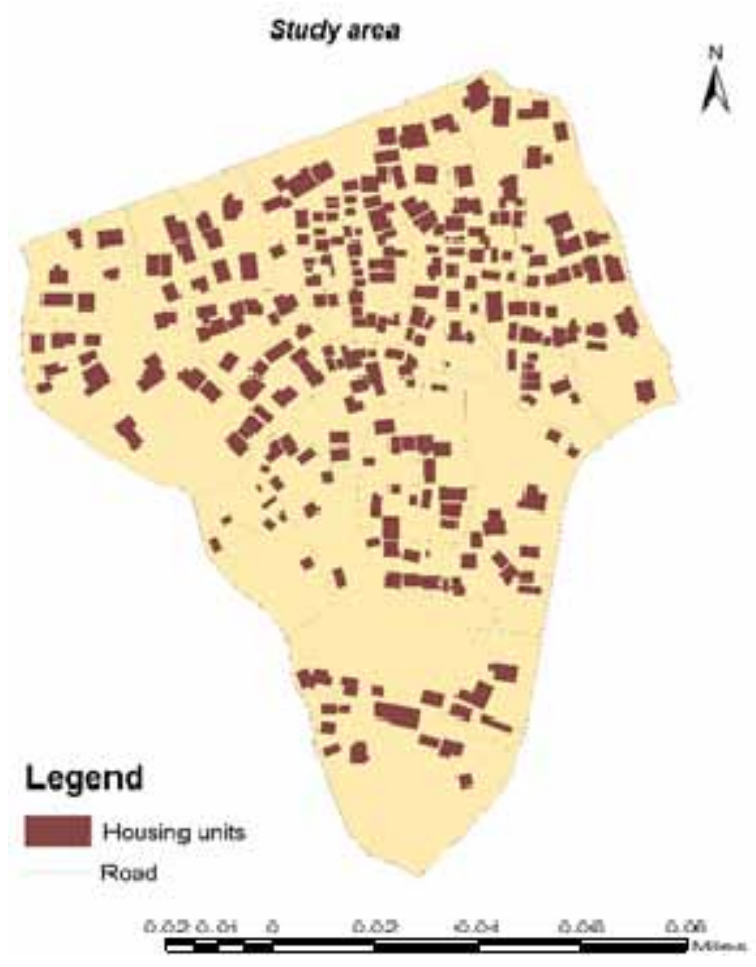

Table 3. Detail of each residential zone

\begin{tabular}{|c|c|c|c|c|}
\hline $\begin{array}{c}\text { Primary residential } \\
\text { Zone }\end{array}$ & $\begin{array}{l}\text { Extent } \\
\text { (Acres) }\end{array}$ & $\%$ & No. of Housing Units & $\%$ \\
\hline Zone 01 & 598 & 5 & 17676 & 3 \\
\hline Zone 02 & 34 & 3 & 214 & 3 \\
\hline Zone 03 & 25 & 2 & 122 & 2 \\
\hline Zone 04 & 306 & 25 & 1620 & 26 \\
\hline Zone 05 & 291 & 24 & 1542 & 24 \\
\hline Zone 06 & 41 & 3 & 280 & 4 \\
\hline Zone 07 & 371 & 31 & 1252 & 20 \\
\hline Zone 08 & 87 & 7 & 1126 & 18 \\
\hline Total & 1214 & & 6332 & \\
\hline
\end{tabular}

\subsubsection{Independent Variables}

See Figure 5.

\subsubsection{Dependent Variable}

Extent of the residential green space maintain by the respondents was measured as follows: 
Figure 5. Relationship between independent and dependent variable

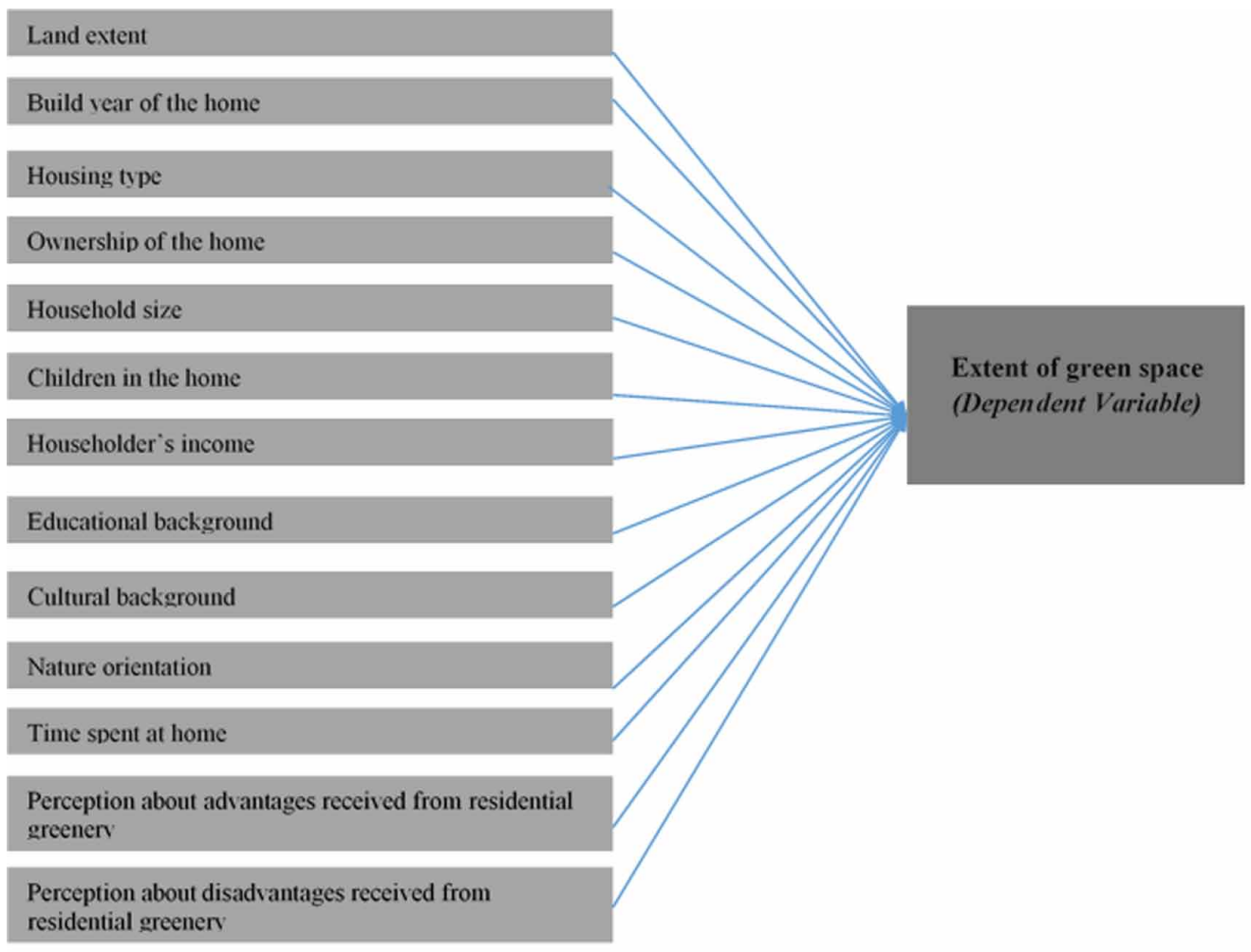

$\mathrm{SRG}=\mathrm{AEG} \times 100$

TUSG

where:

$\mathrm{SRG}=\%$ of space using for residential garden

$\mathrm{AEG}=$ Available Extent of greenery area

TUSG $=$ Total usable space for gardening

\section{ANALYSIS}

Missing data can critically bias the conclusions of a research (Barbara G.Tabachnick \& Fidell, 2001). Therefore, the issue of missing data should be addressed and treated before the analysis. There are no missing values in this study (Appendix B).

\subsection{Reliability and Validity Analysis}

Reliability and validity analysis were done for the three multiple respondent questions of the prepared questionnaire. This research tested reliability using Cronbach's Alpha value, which ranged from 0.70 to 0.95 . In the validation process of the research two basic survey instruments, namely content and construct validity were assessed to get the uniqueness of the measures. 
Table 4. Reliability and validity analysis

\begin{tabular}{|c|c|c|c|c|c|c|c|}
\hline \multirow{2}{*}{ Variable } & \multirow{2}{*}{$\begin{array}{l}\text { No. of } \\
\text { Items }\end{array}$} & \multirow{2}{*}{$\begin{array}{l}\text { Cronbach's } \\
\text { Alpha }\end{array}$} & \multirow{2}{*}{ KMO } & \multicolumn{2}{|c|}{ Bartlett's Test } & \multirow{2}{*}{$\begin{array}{c}\text { Initial } \\
\text { Eigenvalue }\end{array}$} & \multirow{2}{*}{ AVE } \\
\hline & & & & $\begin{array}{l}\text { Chi Square } \\
\text { Value }\end{array}$ & Sig. & & \\
\hline 1. Nature Orientation & 3 & 0.806 & 0.706 & 273.766 & 0.000 & 2.163 & $72.101 \%$ \\
\hline $\begin{array}{l}\text { 2. Perception about advantages } \\
\text { received from residential garden }\end{array}$ & 9 & 0.864 & 0.915 & 964.487 & 0.000 & 4.494 & $49.929 \%$ \\
\hline $\begin{array}{l}\text { 3. Perception about disadvantages } \\
\text { resulting from residential garden }\end{array}$ & 4 & 0.495 & 0.678 & 200.210 & 0.000 & 2.012 & - \\
\hline $\begin{array}{l}\text { 4. Perception about disadvantages } \\
\text { resulting from residential garden } \\
\text { after removing Q1 }\end{array}$ & 3 & 0.749 & 0.683 & 194.478 & 0.000 & 1.998 & $66.589 \%$ \\
\hline
\end{tabular}

Content validity is the subjective assessment of the measures affiliated with the face validity, and this is somewhat informal. All questions in the developed questionnaire were adopted from previous studies. By doing so, content validity was assured.

Researcher tested content validity by using Kaiser-Meyer-Olkin (KMO) measure, Bartlett's test of sphericity, Initial Eigenvalue and Average Variance Extracted (AVE). The value of Kaiser-MeyerOlkin (KMO) should be greater than 0.5 if the sample is adequate (Field, 2005). If Bartlett's test is significant, factor analysis is appropriate to test construct validity (Field, 2005). If the Eigenvalue is greater than 1.00 then the data will support the assumption of unidimensionality (McGill M.T., 2009). The value of AVE for each construct should be at least 0.50 for the construct validity to be accepted (Zait \& Bertea, 2011).

According to Table 4, Cronbach's Alpha values of all variables range from 0.70 to 0.95 except in the case of variable No. 04 - Perception about disadvantages resulting from residential garden. All KMO values are greater than 0.5. Likewise, all Sig values of Bartlett's Test also consistently maintain the condition of values that are less than 0.05 and Initial Eigenvalue as greater than 1 . The AVE values are also above 0.5 except variable No. 04 - Perception about disadvantages resulting from residential garden. Researcher is able to state that all variables are reliable and valid after removing Q1 from Perception about disadvantages resulting from residential garden. Hence, the researcher could safely conclude that the reliability and validity of this research attained a higher position after the elimination of unsuitable questions.

\subsection{Regression Analysis}

Regression analysis is a powerful statistical method that allows one to examine the relationship between two or more variables of interest. In this research, the dependent variable is the extent of green area maintained by the resident. There are altogether 14 independent variables including a few dummy variables.

As shown in Table 5, the $\mathrm{P}$ value of the variable such as land extent, nature orientation, perception about advantages and disadvantages associated with residential greenery, occupational level of husband and wife, and their educational level is greater than 0.05 . Then at $95 \%$ confidence level researcher can say that those factors have an effect on Extent of the green area. Based on the result of analysis the following model is formulated to illustrate the relationship between socio demographic factors influencing to the extent of green space maintain by the urban residence.

\subsection{Developed Regression Model}

$\mathrm{EGA}=0.091+0.003 \mathrm{LE}+0.060 \mathrm{NO}+0.030 \mathrm{PA}-0.040 \mathrm{PDA}+0.198 \mathrm{D}_{1}+0.240 \mathrm{D}_{2}$ $\mathrm{EGA}=$ Extent of the green area 
Table 5. Coefficients ${ }^{\mathrm{a}}$

\begin{tabular}{|c|c|c|c|c|c|}
\hline \multirow{2}{*}{ Model } & \multicolumn{2}{|c|}{ Unstandardized Coefficients } & \multirow{2}{*}{$\begin{array}{c}\begin{array}{c}\text { Standardized } \\
\text { Coefficients }\end{array} \\
\text { Beta }\end{array}$} & \multirow[t]{2}{*}{$\mathbf{t}$} & \multirow[t]{2}{*}{ Sig. } \\
\hline & B & Std. Error & & & \\
\hline (Constant) & 0.091 & 0.173 & & 0.525 & 0.600 \\
\hline Land extent (Perches) & 0.003 & 0.001 & 0.127 & 2.685 & 0.008 \\
\hline Age of the home & 0.000 & 0.001 & 0.015 & 0.337 & 0.736 \\
\hline Household size & 0.008 & 0.010 & 0.060 & 0.854 & 0.394 \\
\hline Number of children at home & -0.004 & 0.013 & -0.019 & -0.281 & 0.779 \\
\hline Average income & $1.204 \mathrm{E}-009$ & 0.000 & 0.000 & 0.008 & 0.994 \\
\hline Total number of hours spent at home & -0.002 & 0.001 & -0.064 & -1.255 & 0.211 \\
\hline Nature Orientation & 0.060 & 0.011 & 0.344 & 5.680 & 0.000 \\
\hline $\begin{array}{l}\text { Perception about advantages } \\
\text { received from residential garden }\end{array}$ & 0.030 & 0.014 & 0.115 & 2.087 & 0.038 \\
\hline $\begin{array}{l}\text { Perception about disadvantages } \\
\text { resulting from residential garden }\end{array}$ & -0.040 & 0.015 & -0.139 & -2.579 & 0.010 \\
\hline Housing type- single storey & -0.064 & 0.056 & -0.144 & -1.134 & 0.258 \\
\hline Housing type- two storey & -0.086 & 0.058 & -0.172 & -1.477 & 0.141 \\
\hline Housing type- more than two storeys & -0.092 & 0.065 & -0.096 & -1.406 & 0.161 \\
\hline Housing type- attached house/ annex & -0.086 & 0.118 & -0.035 & -0.726 & 0.468 \\
\hline Housing type- hut/ shanty & -0.024 & 0.084 & -0.016 & -0.281 & 0.779 \\
\hline Land ownership- owned by member & -0.009 & 0.039 & -0.010 & -0.223 & 0.823 \\
\hline Dual career & 0.129 & 0.080 & 0.271 & 1.611 & 0.108 \\
\hline Only husband works & 0.115 & 0.078 & 0.263 & 1.468 & 0.143 \\
\hline Only wife works & 0.071 & 0.088 & 0.074 & 0.809 & 0.419 \\
\hline Both are non-occupied & 0.198 & 0.084 & 0.176 & 2.363 & 0.019 \\
\hline Lower than $\mathrm{O} / \mathrm{L}$ & -0.042 & 0.075 & -0.091 & -0.568 & 0.571 \\
\hline $\mathrm{O} / \mathrm{L}$ pass & -0.058 & 0.075 & -0.132 & -0.770 & 0.442 \\
\hline $\mathrm{A} / \mathrm{L}$ pass & -0.047 & 0.074 & -0.098 & -0.630 & 0.529 \\
\hline Degree & -0.071 & 0.079 & -0.083 & -0.897 & 0.370 \\
\hline Higher than degree & 0.240 & 0.089 & 0.224 & 2.701 & 0.007 \\
\hline Culture- Buddhism & -0.007 & 0.113 & -0.017 & -0.063 & 0.950 \\
\hline Culture- Islam & -0.026 & 0.114 & -0.062 & -0.230 & 0.818 \\
\hline Culture- Christian & 0.010 & 0.130 & 0.007 & 0.074 & 0.941 \\
\hline
\end{tabular}

\section{LE $=$ Land extent (Perches)}

$\mathrm{NO}=$ Nature Orientation

$\mathrm{PA}=$ Perception about advantages received from residential garden

PDA $=$ Perception about disadvantages resulting from residential garden

$\mathrm{D}_{1}=$ Occupation (Both are non-occupied)

$\mathrm{D}_{2}=$ Education level (Higher than degree) 
Table 6. Overall model significance

\begin{tabular}{|l|l|l|l|l|l|l|}
\hline \multicolumn{2}{|c|}{ ANOVA $^{\mathrm{a}}$} \\
\hline \multirow{3}{*}{1} & Model & Sum of Squares & \multicolumn{1}{|c|}{ df } & Mean Square & \multicolumn{1}{c|}{ F } & Sig. \\
\cline { 2 - 8 } 1 & Regression & 6.833 & 27 & 0.253 & 11.976 & $0.000^{\mathrm{b}}$ \\
\cline { 2 - 7 } & Residual & 5.325 & 252 & 0.021 & & \\
\cline { 2 - 7 } & Total & 12.158 & 279 & & & \\
\hline
\end{tabular}

a. Dependent Variable: Extent of the green area (Source: Author, 2019)

b. Predictors: (Constant), Cultural-Christian, Only husband works, A/L pass, Land ownership- owned by member, Housing type- attached house/ annex, Housing type- two storey, Degree, Perception about disadvantages resulting from residential garden, Housing type- hut/ shanty, Age of the home, Both are non-occupied, Housing type- more than two storey, Number of children at home, Average income, Land extent, Total number of hours spent at home, Perception about advantages received from residential garden, Only wife works, Cultural-Buddhism, Higher than degree, Lower than O/L, Nature Oriented, Household size, Housing type- single storey, Dual career, O/L pass, Cultural-Islam.

\subsubsection{Regression Model Requirement}

Overall model significance was tested by ANOVA Statistic, and it gave a P value of 0.000 , which is less than 0.05 . Researcher can say that this was the overall model significance at $95 \%$ confidence level. Overall model significance means that independent variables in the developed model jointly affected Extent of the green area (Table 6).

\subsubsection{Model Adequacy}

$\mathrm{R}$-squared is 0.562 . It means that $56.2 \%$ of the variation in Extent of the green area can be explained by the following six independent variables: Land extent, Nature Orientation, Perception about advantages received from residential garden, Perception about disadvantages resulting from residential garden, Occupation and Educational level. Therefore, researcher can say that the model is adequate.

Then researcher check regression model assumptions as follows.

\subsubsection{Residual Should Not be Auto Correlation Error}

Residual should not be Auto correlation error, and this can be tested by using Durbin-Watson statistic. According to the model summary (Table 7), Durbin-Watson statistic is 1.854 , which is close to 2 . Therefore, there is no Auto correlation error and the model is appropriate.

\subsubsection{Residual Should Be Normal Distribution}

Residuals are normality or not can be check by using histogram and P-P plot. Histogram has bell shape (Figure 6) and P-P plot's plots closed to the diagonal line (Figure 7). Then researcher can say that residuals are normally distributed.

Table 7. Model Summary

\begin{tabular}{|l|l|l|l|l|l|}
\hline Model & \multicolumn{1}{|c|}{ R } & \multicolumn{1}{|c|}{ R Square } & \multicolumn{1}{|c|}{$\begin{array}{c}\text { Adjusted R } \\
\text { Square }\end{array}$} & Std. Error of the Estimate & $\begin{array}{c}\text { Durbin- } \\
\text { Watson }\end{array}$ \\
\hline 1 & $0.750^{\mathrm{a}}$ & 0.562 & 0.515 & 0.14537 & 1.854 \\
\hline
\end{tabular}

a. Predictors: (Constant), Cultural-Christian, Only husband works, A/L pass, Land ownership- owned by member, Housing type- attached house/ annex, Housing type- two storey, Degree, Perception about disadvantages resulting from residential garden, Housing type- hut/ shanty, Age of the home, Both are non-occupied, Housing type- more than two storey, Number of children at home, Average income, Land extent, Total Number of hours spent at home, Perception about advantages received from residential garden, Only wife works, Cultural-Buddhism, Higher than degree, Lower than O/L, Nature Oriented, Household size, Housing type- single storey, Dual career, O/L pass, Cultural-Islam

b. Dependent Variable: Extent of the green area (Source: Author, 2019) 
International Journal of E-Planning Research

Volume 10 • Issue 1 • January-March 2021

Figure 6. Regression Standardized Residual

\section{Histogram}

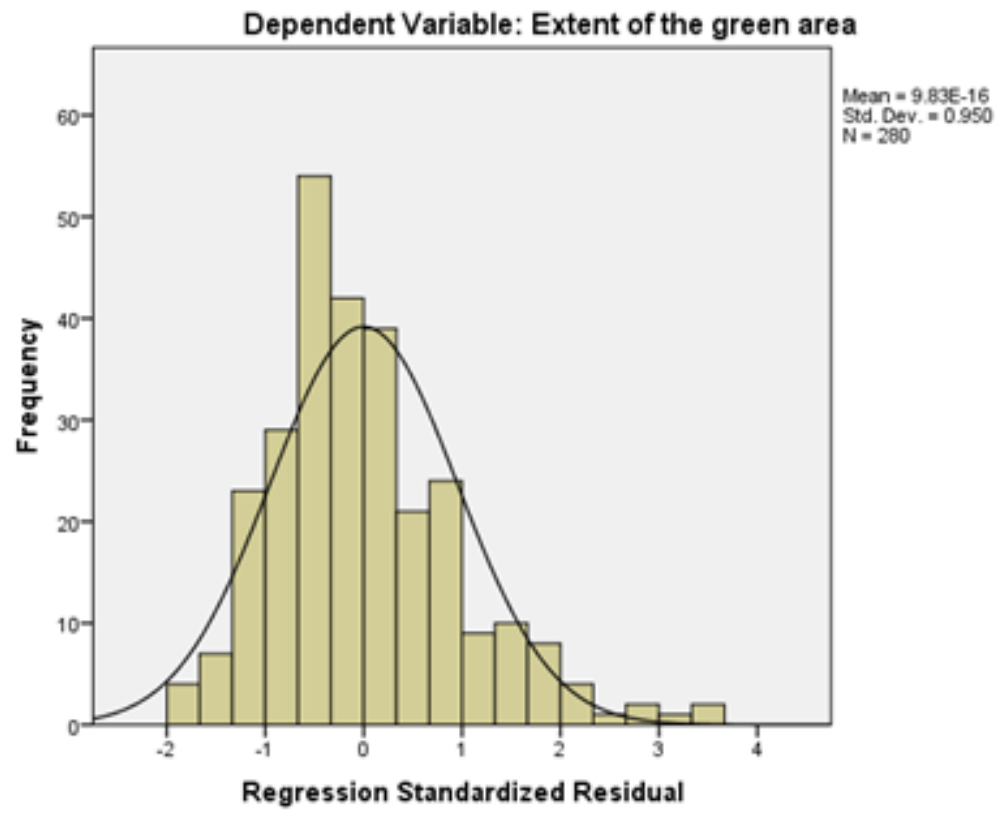

Figure 7. Normal P-P plot of Regression standardized residual

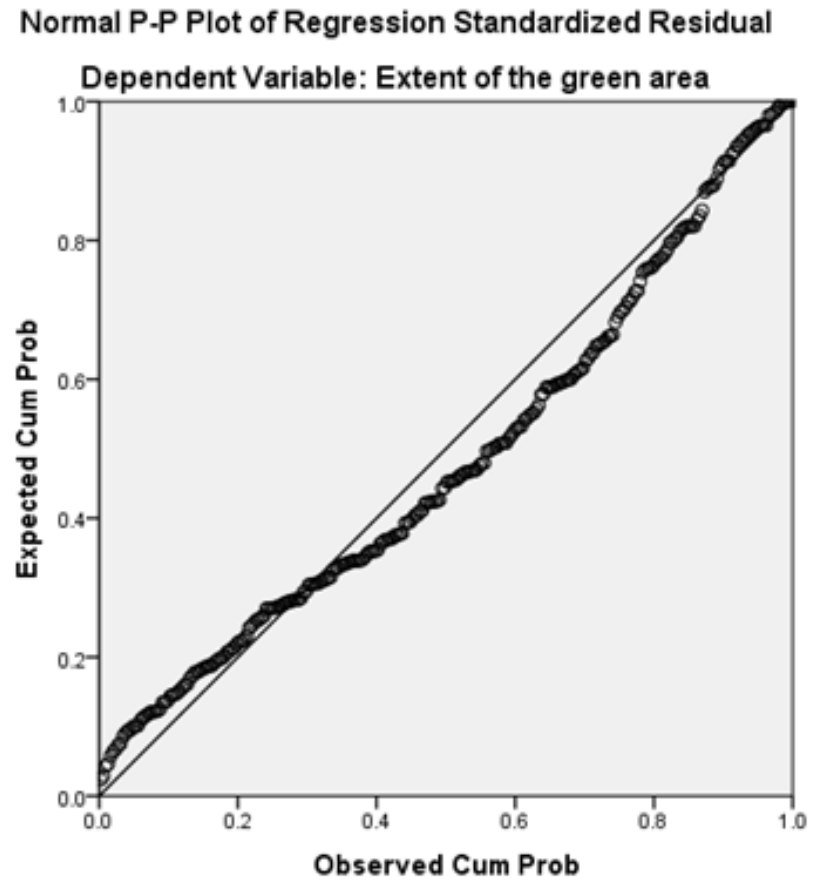




\subsubsection{Residual Are in Homoscedasticity Distribution}

The error lies on systematic pattern says the inadmissible of the model. Thereby, variance of the error is not constant. Hence, if the model is good fit, it should be homoscedasticity. Accordingly, Figure 8 It has not been distributed on systematic pattern. Thus, errors are in homoscedasticity distribution (Residual mean zero and constant variance). Therefore, the regression model is acceptable.

Regression model requirements and assumptions are fulfilled and it means that this model is valid.

\section{RESULTS}

Residential gardens constitute a substantial proportion of the green spaces in Galle City. However, not all residents choose to have, or are able to keep a residential garden. Generally, householders who have less than 6 perches of land are unable to maintain an adequate plot of greenery. Mean extent of the green area maintained by land owners who own less than 6 perches is $18.80 \%$, while $6-10$ perch land owners maintain $21.36 \%, 10-15$ perch land owners maintain 30\%, 15-20 perch land owners maintain $28 \%$ and those who own more than 20 perches maintain $38 \%$. Land extent had a significant positive effect on the Extent of green area maintained by the residents.

Nature Orientation had a significant positive effect on Extent of the green area $(p<0.05, \beta=$ 0.060). This indicates that when the Nature Orientation increases, Extent of the green area will also increase. Mean Extent of the green area maintained by the Nature Oriented People is $33.5 \%$ and Mean Extent of the green area maintain by the non-Nature Oriented People is $16.6 \%$.

Regression beta value for Perception about advantages received from residential garden is 0.038 . This indicates that when Perception about the advantages received from residential gardens increases,

\section{Scatterplot}

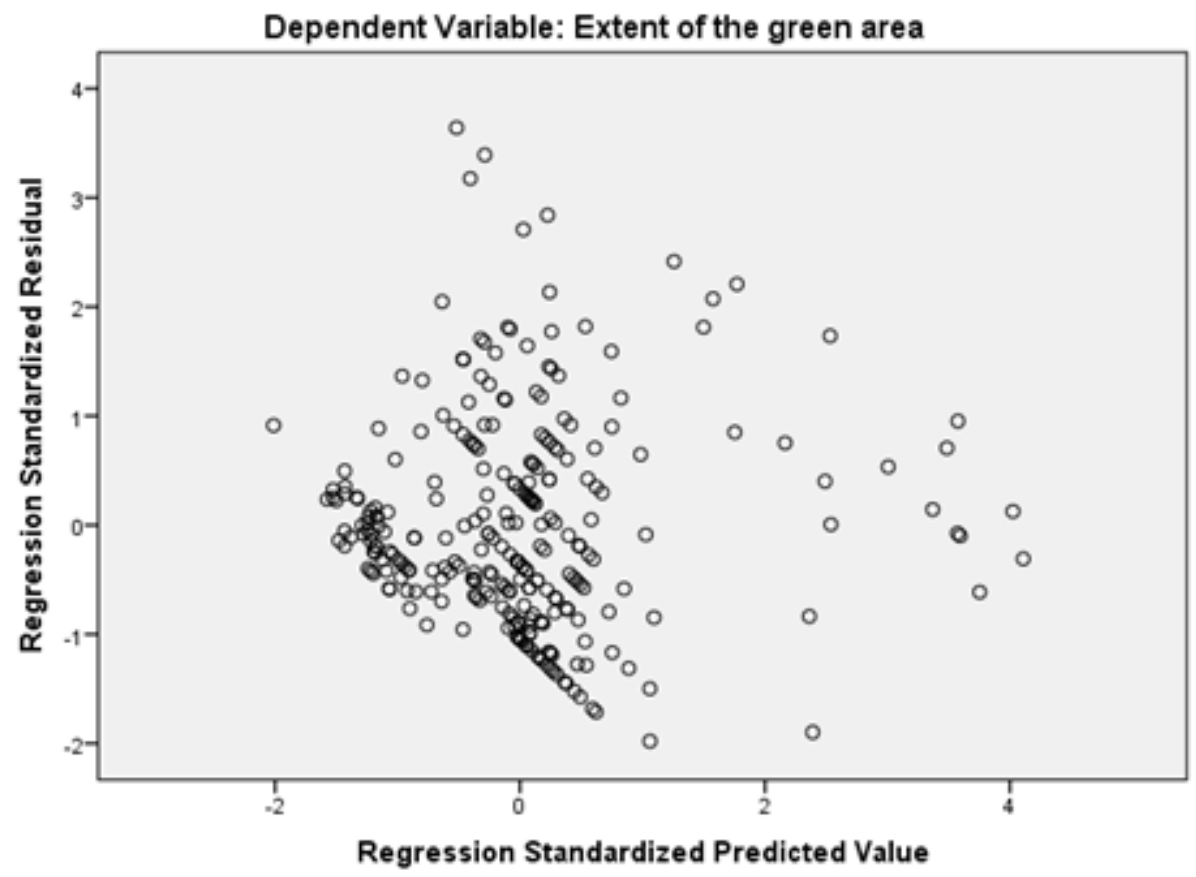


Extent of the green area will also increase. Mean Extent of the green area of people who perceived the advantages received from residential gardens is $27.15 \%$ and Mean Extent of the green area of people who did not perceive the advantages received from residential gardens is $18.05 \%$.

Cameron et al. (2012) found that perceptions of private gardens are not always positive. However, most participants $(27.15 \%)$ of this study enjoyed gardening and found it a therapeutic activity. Residents' benefit from gardens is mostly related to the extent of their gardening practices.

Mean Extent of the green area of people who perceived that disadvantages result from residential gardens is $21.43 \%$ and Mean Extent of the green area of people who did not perceive that disadvantages resulted from residential gardens is $47.8 \%$. Regression beta value for Perception about disadvantages resulting from residential garden is -0.040 . This indicates that when Perception about disadvantages resulting from residential garden increase, Extent of the green area will decrease.

As shown in Table 5, Occupation has a significant effect on Extent of the green area $(\mathrm{p}<0.05)$. Beta value when both husband and wife are non-occupied is 0.198 . This indicates that when husband and wife are non-occupied, Extent of the green area will increase by $19.8 \%$.

According to the Regression Coefficients, $\mathrm{P}$ value of Educational level (higher than degree) is 0.007 , which value is less than 0.05 . Then at $95 \%$ confidence level researcher can say that Educational qualification has an effect on Extent of the green area. Mean Extent of the green area maintained by people whose educational level is higher than a degree is $75.9 \%$.

Findings from our quantitative study indicated that land extent, nature orientation, perception about advantages and disadvantages associated with residential greenery, occupational level of husband and wife, and their educational level significantly affect the extent of green area maintained in urban residences.

Age of the home, housing type, ownership, household size, number of children at home, average income, number of hours spent at home and cultural background do not seem to have any effect on the extent of residential greenery in the study area.

\section{CONCLUSION AND DISCUSSION}

As the world's cities continue to grow, continuing to value green space in cities is vital, but is also a challenge, particularly in developing nations where there is pressure for space, resources and development. Therefore, it is necessary to draw attention on this area and find innovative solutions in this domain.

Urban green spaces are considered a key solution to problems associated with increasing urbanization, such as pollution and urban 'heat island' effect (Kendal et al., 2016; Smith et al., 2006). The green infrastructure of cities includes both public and private green spaces. This paper investigated the socio demographic factors that most influence the size and presence of residential green spaces in an urban environment. The analysis showed that factors such as land extent, nature orientation, and perceptions about advantages and disadvantages of growing residential greenery, occupational status and their educational level significantly affect to the extent of green area maintained by an urban residence.

The present study has some limitations that provide directions for future research. First, the present sample represent the householders living in best residential zone of Galle city and represent only $4 \%$ housing units from all residential zone. Replication of this study in other residential zones is necessary in more representative samples to establish generalization.

Second, the results of this study have shown that it is possible to develop a model that describes the socio demographic factors influence on the size of a residential garden in an urban city. The model can be further improved by considering another variables mentioned in the literature review section of this article. We considered only 14 variables and there are few other variables such as history and types of urban development (Conway \& Hackworth, 2007; Gill, Handley, Ennos, Pauleit, Theuray, \& Lindley, 2008; Smith, Gaston, Warren, \& Thompson, 2005), housing density (Whitford 
et al., 2001) and physical characteristics of cities (Kirkpatrick, Davison, \& Daniels, 2012; Loram et al., 2007; Shanahan et al., 2014; Smith et al., 2005) that influence the size of a residential garden in an urban city. The extent and type of vegetation cover in private gardens vary in accordance with the biological variables such as rail fall, soil fertility, solar radiation (Luck et al,2009). These variables can be used to further develop this research study.

The results of this study can support public authorities and urban planners as they strive to effectively design and manage urban green spaces. The presence of private gardens reduces the need for public green spaces therefore future greening initiatives should focus on residential green spaces. Under the present circumstance, there are no planning guidelines and standards to encourage greenery in residential lands in Sri Lanka. From the results, we proposed that regulations for green coverage with proportion to the lot size is needed to sustain the urban greenery in Sri Lanka. 


\section{REFERENCES}

Arnold, J. E., \& Lang, U. A. (2007). Changing American home life: Trends in domestic leisure and storage among middle-class families. Journal of Family and Economic Issues, 28(1), 23-48. doi:10.1007/s10834-006-9052-5

Barbara, G. T., \& Fidell, L. S. (2001). Using Multivariate Statistics (4th ed.). Allyn \& Bacon.

Blaylock, J., \& Gallo, A. (1993). Modelling the decision to produce vegetables at home. American Journal of Agricultural.

Bolund, P., \& Hunhammar, S. (1999). Ecosystem services in urban areas. Ecological Economics, 29(2), $293-30$. doi:10.1016/S0921-8009(99)00013-0

Bowler, D. E., Buyung-Ali, L., Knight, T. M., \& Pullin, A. S. (2010). Urban greening to cool towns and cities: A systematic review of the empirical evidence. Landscape and Urban Planning, 97(3), 147-155. doi:10.1016/j. landurbplan.2010.05.006

Byomkesh, T., Nakagoshi, N., \& Dewan, A. M. (2012). Urbanization and green space dynamics in Greater Dhaka, Bangladesh. -. Landscape and Ecological Engineering, 8(1), 45-58. doi:10.1007/s11355-010-0147-7

Jayasinghe. (2018). Measuring the suitability of urban residential zone in Galle city: a GIS analysis. In $6^{\text {th }}$ International Urban design Conference ICCPP-2018 (pp. 48-70). Department of Architecture, University of Moratuwa.

Cameron, R. W. F., Blanuša, T., Taylor, J. E., Salisbury, A., Halstead, A. J., Henricot, B., \& Thompson, K. (2012). The domestic garden - Its contribution to urban green infrastructure. Urban Forestry \& Urban Greening, 11(2), 129-137. DOI:.ufug.2012.01.00210.1016/j

Cervinka, R., Schwab, M., Schönbauer, R., Hämmerle, I., Pirgie, L., \& Sudkamp, J. (2016). My garden- my mate? Perceived restorativeness of private gardens and its predictors. Urban Forestry \& Urban Greening, 16, 182-187. DOI: .ufug.2016.01.0110.1016/j

Chang, C.-R., Li, M.-H., \& Chang, S.-D. (2007). A preliminary study on the local cool-island intensity of Taipei City parks. Landscape and Urban Planning, 80(1-2), 45-55. doi:10.1016/j.landurbplan.2006.09.005

Chen, Y., \& Wong, N. H. (2006). Thermal benefits of city parks. Energy and Building, 38(2), $105-120$. doi:10.1016/j.enbuild.2005.04.003

Cheng, E., \& Pegg, S. (2016). "If I'm not gardening, I'm not at my happiest": Exploring the positive subjective experiences derived from serious leisure gardening by older adults. World Leisure Journal, 58(4), 285-297. DO I:.2016.122821910.1080/16078055

Clarke, L. W., Jenerette, G. D., \& Davila, A. (2013). The luxury of vegetation and the legacy of tree biodiversity in Los Angeles, CA. Landscape and Urban Planning, 116, 48-59. doi:10.1016/j.landurbplan.2013.04.006

Clayton, S. (2007). Domesticated nature: Motivations for gardening and perceptions of environmental impact. Journal of Environmental Psychology, 27(3), 215-224. doi:10.1016/j.jenvp.2007.06.001

Conway, T., \& Hackworth, J. (2007). Urban pattern and land cover variation in the greater Toronto area. greater Toronto area. The Canadian Geographer. Geographe Canadien, 51(1).

Daniels, G. D., \& Kirkpatrick, J. B. (2006). Comparing the characteristics of front and back domestic gardens in Hobart, Tasmania, Australia. Landscape and Urban Planning, 78, 344-352.

Douglas. (2012). Urban ecology and urban ecosystems: Understanding the links to human health and well-being. Economics, 65, 722-729.

Mool. (2014). Regression analysis. DOI: 10.1007/978-3-642-53965-7_7

European Commission. (2013). Building a Green Infrastructure for Europe. Publications Office of the European Union. doi:10.2779/54125

Field, A. P. (2005). Discovering statistics using SPSS (2nd ed.). London: Sage. 
Frumkin, H. (2013). The evidence of nature and the nature of evidence. American Journal of Preventive Medicine, 44(2), 196-197. doi:10.1016/j.amepre.2012.10.016 PMID:23332341

Fuller, R. A., Irvine, K. A., Devine-Wright, P., Warren, P. H., \& Gaston, K. J. (2007). Psychological benefits of greenspace increase with biodiversity. Biology Letters, 3(4), 390-394. doi:10.1098/rsbl.2007.0149 PMID: 17504734

Gaston, K. J., Warren, P. H., Thompson, K., \& Smith, R. M. (2005). Urban Domestic Gardens (IV): The Extent of the Resource and its Associated Features. Biodiversity and Conservation, 14(14), 3327-3349. doi:10.1007/ s10531-004-9513-9

Ghosh, S., Vale, R., \& Vale, B. (2008). Local food production in home gardens: Measuring on site sustainability potential of residential development. International Journal of Environment and Sustainable Development, 7(4), 430-451. doi:10.1504/IJESD.2008.022388

Gilbert, M., \& Brack, C. L. (2007). Changes in public requests to remove significant urban trees after severe bushfires in Canberra Australia. Urban Forestry \& Urban Greening, 6(1), 41-48. doi:10.1016/j.ufug.2006.10.001

Gill, S. E., Handley, J. F., Ennos, A. R., \& Pauleit, S. (2007). Adapting cities for climate change: The role of the green infrastructure. Built Environment, 33(1), 115-133. doi:10.2148/benv.33.1.115

Gobster, P. H., \& Westphal, L. M. (2004). The human dimensions of urban greenways: Planning for recreation and related experiences. Landscape and Urban Planning, 68(2), 147-165. 10.1016/S0169-2046(03)00162-2

Graesch, A. P., Broege, N., Arnold, J. E., Owens, A., \& Schneider, B. (2006). Family activities, uses of space, and emotional well being: a collaborative merging of time diary and ethnoarchaeological data. Working Paper 44. Los Angeles: UCLA Center on Everyday Lives of Families. http://www.celf.ucla.edu/pages/view abstractf1ab. html?AID $=54$

Greene, C. S., Millward, A. A., \& Ceh, B. (2011). Who is likely to plant a tree? The useof public sociodemographic data to characterize client participants in a private urban forestation program. Urban Forestry \& Urban Greening, 10(1), 29-38. doi:10.1016/j.ufug.2010.11.004

Grove, J. M., Troy, A. R., O’Neil-Dunne, J. P. M., Burch, W. R. Jr, Cadenasso, M. L., \& Pickett, S. T. A. (2006). Characterization of households and its implications forthe vegetation of urban ecosystems. Ecosystems (New York, N.Y.), 9(4), 578-597. doi:10.1007/s10021-006-0116-Z

Head, L., Muir, P., \& Hampel, E. (2005). Australian backyard gardens and the journey of migration. Geographical Review, 94(3), 326-347. doi:10.1111/j.1931-0846.2004.tb00176.x

Ho, C. H., Sasidharan, V., Elmendorf, W., Willits, F. K., Graefe, A., \& Godbey, G. (2005). Gender and ethnic variations in urban park preferences, visitation, andperceived benefits. Journal of Leisure Research, 37(3), 281-306. doi:10.1080/00222216.2005.11950054

Hope, D., Gries, C., Zhu, W., Fagan, W. F., Redman, C. L., Grimm, N. B., Nelson, A. L., Martin, C., \& Kinzig, A. (2003). Socioeconomics drive urban plant diversity. Proceedings of the National Academy of Sciences of the United States of America, 100(15), 8788-8792. doi:10.1073/pnas.1537557100 PMID:12847293

Jauregui, E. (1990/1991). Influence of a large urban park on temperature and convective precipitation in a tropical city. Energy and Building, 15(3-4), 457-463. doi:10.1016/0378-7788(90)90021-A

Jim, C. Y., \& Chen, S. S. (2003). Comprehensive greenspace planning based on landscape ecology principles in compact Nanjing city, China. Landscape and Urban Planning, 65(3), 95-116. doi:10.1016/S01692046(02)00244-X

Kabisch, N., Qureshi, S., \& Haase, D. (2015). Human- environment interactions in urban green spaces- A systematic review of contemporary issues and prospects for future research. Environmental Impact Assessment Review, 50, 25-34. doi:10.1016/j.eiar.2014.08.007

Kendal, D., Lee, K., Ramalho, C., Bowen, K., \& Bush, J. (2016). Benefits of Urban Green Space in the Australian Context. Academic Press.

Kendal, D., Williams, N. S., \& Williams, K. J. (2012). Drivers of diversity and tree cover in gardens, parks and streetscapes in an Australian city. Urban Forestry \& Urban Greening, 11(3), 257-265. doi:10.1016/j. ufug.2012.03.00 
Kirkpatrick, J., Daniels, G., \& Davison, A. (2011). Temporal and spatial variation in garden and street trees in six eastern Australian cities. Landscape and Urban Planning, 101(3), 244-252. doi:10.1016/j. landurbplan.2011.02.029

Kirkpatrick, J., Daniels, G., \& Zagorski, T. (2007). Explaining variation in front gardens between suburbs of Hobart, Tasmania, Australia. Landscape and Urban Planning, 79(3), 314-322. doi:10.1016/j.landurbplan.2006.03.006

Kong, F., Yin, H., Nakagoshi, N., \& Zong, Y. (2010). Urban green space network development for biodiversity conservation: Identification based on graph theory and gravity modeling. Landscape and Urban Planning, 95(1), 16-27. doi:10.1016/j.landurbplan.2009.11.001

Kortright, R. (2007). Edible Backyards: Residential land use for food production in Toronto (Unpublished master's thesis). University of Toronto, Ontario, Canada. Retrieved October, 15, 2008 from https://www.utoronto.ca/cuhi/ research/supportingdocs/EdibleBackyardsReport.pdf

Lee, A. C., \& Maheswaran, R. (2011). The health benefits of urban green spaces: A review of the evidence. Journal of Public Health, 33(2), 212-222. doi:10.1093/pubmed/fdq068 PMID:20833671

Lin, B., Fuller, R. A., Bush, R., Gaston, K. J., \& Shanahan, D. F. (2015). Opportunity or orientation? Who uses urban parks and why. PLoS One, 9(1), e87422. doi:10.1371/journal.pone.0087422 PMID:24489913

Loibl, W., \& Toetzer, T. (2003). Modeling growth and densification processes insuburban regions-Simulation of landscape transition with spatial agents. Environmental Modelling \& Software, 18(6), 553-563. doi:10.1016/ S1364-8152(03)00030-6

Loram, A., Tratalos, J., Warren, P. H., \& Gaston, K. J. (2007). Urban domestic gardens (X): The extent \& structure of the resource in five major cities. Landscape Ecology, 22(4), 601-615. doi:10.1007/s10980-006-9051

Lowry, J. H., Baker, M. E., \& Ramsey, R. D. (2012). Determinants of urban tree canopy in residential neighborhoods: Household characteristics, urban form, and the geophysical landscape. Urban Ecosystems, 15, 247-266. doi:10.1007/s11252-011-0185-4

Luck, G. W., Smallbone, L. T., \& O’Brien, R. (2009). Socio-economics and vegetation change in urban ecosystems: Patterns in space and time. Ecosystems (New York, N.Y.), 12(4), 604. doi:10.1007/s10021009-9244

Mathieu, R., Freeman, C., \& Aryal, J. (2007). Mapping private gardens in urban areas using object-oriented techniques and very highresolution satellite imagery. Landscape and Urban Planning, 81(3), 179-192. doi:10.1016/j.landurbplan.2006.11.00

Maxwell, D. G. (1995). Alternative food security strategy: A household analysis of urban agriculture in Kampala. World Development, 23(10), 1669-1681. doi:10.1016/0305-750X(95)00073-L

Mazereeuw, B. (2005). Urban Agriculture Report. Waterloo, Ontario, Canada: Region of Waterloo. Public Health.

McGill, M.T. (2009). An Investigation of Unidimensional Testing Procedures under Latent Trait Theory using Principal Component Analysis. Academic Press.

McPherson, E. G., Herrington, L. P., \& Heisler, G. M. (1988). Impacts of vegetation on residential heating and cooling. Energy and Building, 12(1), 41-51. doi:10.1016/0378-7788(88)90054-0

McPherson, E. G., Simpson, J. R., \& Livingston, M. (1998). Effects of landscape treatments on residential energy and water-use in Tucson, Arizona. Energy and Building, 13, 127138.

McPherson, E. (1994). Cooling urban heat islands with sustainable landscapes. In R. H. Platt, R. A. Rowntree, \& P. C. Muick (Eds.), The ecological city: preserving andrestoring urban biodiversity (pp. 151-171). Univ of Massachusetts Press Amherst.

McPherson, E. G., \& Simpson, J. R. (2002). A comparison of municipal forest benefits and costs in Modesto and Santa Monica, California, USA. Urban Forestry \& Urban Greening, 1(2), 61-74. doi:10.1078/1618-8667-00007

Miura, S., Kunii, O., \& Wakai, S. (2003). Home gardening in urban poor communities of the Philippines. International Journal of Food Sciences and Nutrition, 54(1), 77-88. doi:10.1080/0963748031000062010 PMID:12701239 
Moustier, P., \& Danso, G. (2006). Local economic development and markets of urban produced food. In R. van Veenhuisen (Ed.), Cities farming for the future: urban agriculture for green and productive cities (pp. 173-208). RUAF Foundation, International Institute of Rural Reconstruction, International Development Research Centre.

Mwangi, A. M. (1995). The role of urban agriculture for food security in low income areas in Nairobi (Report No. 54). Nairobi, Kenya: African Studies Centre, Food and Nutrition Studies Programme.

Nasar, J. L., \& Jones, K. M. (1997). Landscapes of fear and stress. Environment and Behavior, 29(3), $291-323$. doi:10.1177/001391659702900301

Nowak, D. J., \& Dwyer, J. F. (2007). Understanding the benefits and costs of urban forest ecosystems. In Urban and community forestry in the northeast (pp. 25-46). Springer. doi:10.1007/978-1-4020-4289-8_2

Perkins, H. A., Heynen, N., \& Wilson, J. (2004). Inequitable access to urban reforestation: The impact of urban political economy on housing tenure and urban forests. Cities, 21, 291-299. .00210.1016/j.cities.2004.04

Peters, K., Elands, B., \& Buijs, A. (2010). Social interactions in urban parks: Stimulating social cohesion? Urban Forestry \& Urban Greening, 9(2), 93-100. doi:10.1016/j.ufug.2009.11.003

Pushpakumara, Wijesekara, \& Hunter. (2010). Kandyan homegardens: a promising land management system in Sri Lanka. In Sustainable use of biological diversity in socio-ecological production landscapes. Background to the 'Satoyama Initiative for the benefit of biodiversity and human well-being. Academic Press.

Radeloff, V. C., Hammer, R. B., \& Stewart, S. I. (2005). Rural and suburban sprawl in the US Midwest from 1940 to 2000 and its relation to forest fragmentation. Conservation Biology, 19(3), 793-805. .2005.00387. x10.1111/j.1523-1739

Shanahan, D., Fuller, R. A., Bush, R., Lin, B. B., \& Gaston, K. J. (2015). The Health Benefits of Urban Nature: How Much Do We Need? Bioscience, 65(5), 476-485. doi:10.1093/biosci/biv032

Shanahan, D. F., Lin, B. B., Gaston, K. J., Bush, R., \& Fuller, R. A. (2014). Socio-economic inequalities in access to nature on public and private lands: A case study from Brisbane, Australia. Landscape and Urban Planning, 130, 14-23. doi:10.1016/j.landurbplan.2014.06.005

Smith, R. M., Gaston, K. J., Warren, P. H., \& Thompson, K. (2006). Urban domestic gardens (VIII): Environmental correlates of invertebrate abundance. Biodiversity and Conservation, 15(8), 2515-2545. doi:10.1007/s10531005-2784-y

Smith, R. M., Thompson, K., Hodgson, J. G., Warren, P. H., \& Gaston, K. J. (2005). Urban domestic gardens (IX): Composition and richness of the vascular plant flora, and implications for native biodiversity. Biological Conservation, 129(3), 312322. doi:10.1016/j.biocon.2005.10.045

Swanwick, C., Dunnett, N., \& Woolley, H. (2003). Nature, role and value of greenspace in towns and cities: An overview. Built Environment, 29(2), 94-106. doi:10.2148/benv.29.2.94.54467

Tabachnick, B. G., \& Fidell, L. S. (2013). Using Multivariate Statistics (6th ed.). Allyn \& Bacon.

Taylor, L., \& Hochuli, D. F. (2015). Creating better cities: How biodiversity and ecosystem functioning enhance urban residents' wellbeing. Urban Ecosystems, 18(3), 747-762. doi:10.1007/s11252-014-0427-3

Troy, A. R., Grove, J. M., O’Neil-Dunne, J. P. M., Pickett, S. T. A., \& Cadenasso, M. L. (2007). Predicting opportunities for greening and patterns of vegetation on private urban lands. Environmental Management, 40(3), 394-412. doi:10.1007/s00267-006-0112-2 PMID:17602257

Tyrvainen, L. (1997). The amenity value of the urban forest: An application of the hedonic pricing method. Landscape and Urban Planning, 37(3), 211-222. doi:10.1016/S0169-2046(97)80005-9

United Nations Department of Economic and Social Affairs, Population Division. (2015). World Urbanization Prospects: The 2014 Revision. Author.

United Nations. (2014). World Urbanization Prospects: The 2014 Revision, Highlights. Department of Economic and Social Affairs. Population Division, United Nations.

Urban Council Ordinance. (1865). Department of Government printing. 
Van Heezik, Y., Freeman, C., Porter, S., \& Dickinson, K. J. M. (2013). Garden size, householder knowledge, and socio-economic status influence plant and bird diversity at the scale of individual gardens. Ecosystems (New York, N.Y.), 16(8), 1442-1454. doi:10.1007/s10021-013-9694-8

Vickery, M. L. (1995). Gardens: the neglected habitat. In A. S. Pullin (Ed.), Ecology and Conservation of Butterflies (pp. 123-134). Chapman and Hall. doi:10.1007/978-94-011-1282-6_9

Whitford, V., Ennos, A. R., \& Handley, J. F. (2001). “City form and natural process”- -indicators for the ecological performance of urban areas and their application to Merseyside, UK. Landscape and Urban Planning, 57(2), 91-103. doi:10.1016/ S0169-2046(01)00192

Zait \& Bertea. (2011). Methods for testing discriminant validity. Management \& Marketing, 6(2).

Zanon, D., Doucouliagos, C., Hall, J., \& Lockstone-Binney, L. (2013). Constraints to park visitation: A metaanalysis of North American studies. Leisure Sciences, 35(5), 475-493. doi:10.1080/01490400.2013.831294 


\section{APPENDIX A. IDENTIFICATION OF SOCIO DEMOGRAPHIC FACTORS INFLUENCE TO THE FUNCTIONS OF RESIDENTIAL GARDENS}

\section{Land extent:}

2. Extent of the greenery area:

3. \% of area using as residential garden as a proportion to the total land space can be used as gardening?

$\frac{\text { Extent of greenery area }}{\text { Total usable space for gardening }} \times 100=$

4. Age of the house:

5. Housing types:

\begin{tabular}{|l|l|l|l|l|l|}
\hline $\begin{array}{l}\text { Single } \\
\text { house- } \\
\text { Single story }\end{array}$ & $\begin{array}{l}\text { Single } \\
\text { house- } \\
\text { Two story }\end{array}$ & $\begin{array}{l}\text { Single story- } \\
\text { more than } \\
\text { two story }\end{array}$ & $\begin{array}{l}\text { Attached } \\
\text { house/annex }\end{array}$ & $\begin{array}{l}\text { Raw house/line } \\
\text { house }\end{array}$ & Hut/shanty \\
\hline & & & & & \\
\hline
\end{tabular}

6. Land ownership:

\begin{tabular}{|l|l|l|l|}
\hline $\begin{array}{l}\text { Owned by a member } \\
\text { of the household }\end{array}$ & Rent & Leased & Encroached \\
\hline & & & \\
\hline
\end{tabular}

7. Householder's size:

8. Number of children in the home:

9. Occupation:

\begin{tabular}{|l|l|l|l|}
\hline Dual carrier & Only husband work & Only wife work & Both are non-occupied \\
\hline & & & \\
\hline
\end{tabular}

10. Householders average income per month:

11. Educational background:

\begin{tabular}{|l|l|l|l|l|}
\hline Less than $\mathrm{O} / \mathrm{L}$ & $\mathrm{O} / \mathrm{L}$ pass & A/L pass & degree & Above degree \\
\hline & & & & \\
\hline
\end{tabular}

12. Cultural background:

\begin{tabular}{|l|l|l|l|}
\hline Buddhism & Hinduism & Islam & Christianity \\
\hline & & & \\
\hline
\end{tabular}

13. Time spent at home $(6.00 \mathrm{am}$ to $6.00 \mathrm{pm})$ :

\begin{tabular}{|l|l|}
\hline husband & \\
\hline wife & \\
\hline Others & \\
\hline Total & \\
\hline
\end{tabular}

14. Are you nature oriented?

\begin{tabular}{|l|l|l|l|l|l|}
\hline & SA & A & N & D & SD \\
\hline a) I would prefer to visit nature related places during my free time & & & & & \\
\hline b) I prefer to gardening as my hobby & & & & & \\
\hline c) I never approve the cutting of trees & & & & & \\
\hline
\end{tabular}


15. What is your perception about advantages receiving from residential garden?

\begin{tabular}{|c|c|c|c|c|c|}
\hline & SA & A & $\mathrm{N}$ & $\mathrm{D}$ & SD \\
\hline a) Contact with nature & & & & & \\
\hline b) Leisure activities with family, friends & & & & & \\
\hline c) Provide opportunities to improve mental health \& physical fitness & & & & & \\
\hline d) Provide habitat for wild life, aiding biodiversity & & & & & \\
\hline e) Help to stabilize urban temperature $\&$ humidity & & & & & \\
\hline f) Absorb pollutants in air \& ground water & & & & & \\
\hline g) Slow storm water runoff and reduce drainage infrastructure & & & & & \\
\hline h) Receiving Food \& medicine & & & & & \\
\hline i) Increase the house value & & & & & \\
\hline
\end{tabular}

16. What is your perception about the disadvantages of a residential garden?

\begin{tabular}{|l|l|l|l|l|l|}
\hline & SA & A & N & D & SD \\
\hline a) Presence of urban vegetation will create fear of crime & & & & & \\
\hline b) Tree maintenance require time, effort, knowledge \& space & & & & & \\
\hline c) it will reduce the space for other activities & & & & & \\
\hline d) $\begin{array}{l}\text { vegetation around home can cause root damage or threaten other } \\
\text { infrastructure with fallen limbs creating safety issues }\end{array}$ & & & & \\
\hline
\end{tabular}




\section{APPENDIX B. UNIVARIATE STATISTICS}

Table 8. Univariate Statistics

\begin{tabular}{|c|c|c|c|c|c|}
\hline & & & & & ing \\
\hline & $\mathbf{N}$ & Mean & Std. Deviation & Count & Percent \\
\hline M5kQ1 & 280 & 2.75 & 1.464 & 0 & .0 \\
\hline M5kQ2 & 280 & 2.55 & 1.354 & 0 & .0 \\
\hline M5kQ3 & 280 & 3.36 & 1.410 & 0 & .0 \\
\hline M51Q1 & 280 & 3.79 & 1.190 & 0 & .0 \\
\hline M51Q2 & 280 & 3.42 & 1.281 & 0 & .0 \\
\hline M51Q3 & 280 & 2.95 & 1.355 & 0 & .0 \\
\hline M51Q4 & 280 & 3.81 & 1.065 & 0 & .0 \\
\hline M51Q5 & 280 & 3.30 & 1.165 & 0 & .0 \\
\hline M51Q6 & 280 & 3.12 & .958 & 0 & .0 \\
\hline M51Q7 & 280 & 3.39 & 1.177 & 0 & .0 \\
\hline M51Q8 & 280 & 3.84 & .941 & 0 & .0 \\
\hline M51Q9 & 280 & 2.58 & 1.158 & 0 & .0 \\
\hline M5mQ1 & 280 & 3.39 & 1.263 & 0 & .0 \\
\hline M5mQ2 & 280 & 3.90 & 1.109 & 0 & .0 \\
\hline M5mQ3 & 280 & 3.79 & 1.121 & 0 & .0 \\
\hline M5mQ4 & 280 & 3.91 & 1.119 & 0 & .0 \\
\hline
\end{tabular}

D. B. C. Jayasinghe received her BSc (Honors) degree in Town and Country Planning from the University of Moratuwa. She pursued her Master degree in public administration and management at the University of Colombo and she is PhD candidate from University of Ruhuna and charted member of the Institute of Town Planners, Sri Lanka.

G. P. T. S. Hemakumara (PhD) is a Profssor in the Department of Geography, University of Ruhuna, Sri Lanka, Professor Hemakumara has completed his PhD at the Universiti Sains Malaysia (USM) under the Professor Ruslan Rainis in 2015. Also obtained a BA Honours degree in Geography from the University of Colombo in 1996, a Masters Degree in Remote Sensing and GIS at AIT, Bangkok in 2001 and the Postgraduate Diploma in Town and Country Planning at the University of Moratuwa. Before he joined the University of Ruhuna, he was an Assistant Director in the GIS section of the UDA of Sri Lanka where he obtained considerable industrial practice and experience in city planning. He is a Chartered Member of the Institute of Town Planners, Sri Lanka.

Piyadasa Hewage $(P h D)$ is a Senior Professor attached to the Department of Geography, University of Ruhuna, Sri Lanka and currently Head, Department of Geography and the Chairman of the Board of Study, Faculty of Humanities \& Social Sciences, University of Ruhuna. Prof. Hewage obtained BA in Geography from University of Colombo, MSc in Medical Demography from University of London, MA in Geography from University of Colombo, and PhD from University of Ruhuna. 